\title{
A Fresh View On Zakah As A Socio- Financial Tool To Promote Ethics, Eliminate Riba And Reduce Poverty
}

\author{
Magda Ismail Abdel Mohsin
}

\author{
International Centre for Education in Islamic Finance, Malaysia
}

\begin{abstract}
Current statistical data shows that almost all Muslim countries are facing economic and social problems such as the spread of poverty, mounting outstanding external debt due to compound interest and widespread unethical behaviour. Some contemporary scholars relate these problems to the oppression and the crippling policies of former colonial administrations, while others point to the governmental incompetence and corruption that triggered the last Arab spring. However, this paper contends that although the above mentioned issues may have served as catalysts that led to the worsening of socio-economic situation in many countries, the main reason for the overwhelming problems plaguing Muslim countries is their neglect of many Islamic financial and socio-financial duties, including zakah (alms) which is conceived to spread ethical behaviour, eliminate riba (interest), empower the poor and needy and so reduce and may even end poverty. This study aims to demonstrate how zakah, as a socio-financial tool, can help promote sound standards of ethics, generate funds to counter external borrowing endorsed by anti-poverty programmes, empower the poor, and eradicate poverty in Muslim societies. This paper uses a secondary source based meta-analysis of books, articles, journals, annual reports, and websites, besides referring to the Quran and the Sunnah of the Prophet (PBUH) whenever necessary. The findings show it is imperative that zakah to be recognised as an effective sociofinancial tool to counter the ills currently plaguing Muslim societies. Adequately managed and distributed zakah can help to promote good ethics, overreliance on external borrowing, empower the poor and end their poverty hence, resulting in a just and a caring society.
\end{abstract}

Keywords: zakah, socio-finance, ethics, riba, poverty alleviation, caring society 


\section{Introduction}

With the end of the Ottoman Empire in the nineteenth century and colonisation, which took place in almost all Muslim countries in the twentieth century, many Muslim countries were forced to follow secular systems counter to the teachings of Islam. For example, the issue of interest or riba in financial sectors is of particular significance as it contributed to the development of a secular taxation system, effectively replacing the institution of zakah (compulsory alms being one of the pillars of Islam). Since then, zakah, one of Islam's socio-financial tools, has been placed in the domain of religious authorities and contribution has been left to individuals' decisions. As such, its remittance became voluntary in almost all Muslim countries, creating ambiguity in the understanding of this concept amongst many Muslims today. Some believe that a combination of disbursements, such as paying zakah and their current taxes, will cover alms related obligations. Other more sincere givers may find themselves parting with ever greater outlays as they may feel obliged to pay both compulsory taxes and the obligatory zakah. Still others may circulate their zakah among relatives and friends rather than considering the designated eight categories of zakah recipients (Al Qardawi, 1999; Muneeza, 2017; Shah and Hassan, 2017).

The objective of this study is to present the practical implication of the importance of zakah as a socio-financial tool that can re-circulate the wealth on a regular basis from the wealthier ('the have') to less fortunate ('the have not') in such a way that it will enhance the ethics of both givers and recipients of zakah, stop recipients from borrowing with riba, and hence reduce poverty. This will be achieved by dividing this paper into six sections, the introduction, literature review, shariah framework of zakah, challenges and obstacles facing zakah today, practical implications for zakah as a socio-financial tool to promoting sound ethics, eliminating riba, empowering the poor, and ending poverty, followed by the conclusion and policy recommendations.

\section{Overview of Zakah}

\subsection{Definition of Zakah}

Literally zakah means purifying, blessing and increasing the wealth of the giver. As one of the pillars of Islam, its giving is compulsory once the wealth reaches al-nisab (the minimum assigned) on a yearly basis; those who have not reach al-nisab are not obliged to pay zakah. Zakahable wealth is divided into two categories: zakah al-Fitrah and zakah on wealth. Zakah al-Fitrah is given during the month of Ramadan and zakah on wealth includes more than fourteen types of zakahable wealth including gold, jewellery, silver currency, fixed capital, rented buildings, commercial assets, agricultural products, honey and animal products, livestock, profits from mining and fishing, besides, zakah on salary, wages, bonuses, grants, gifts, and dividends (Al Qardawi, 1999; Abdullah and Sapiei, 2018).

The recipients of zakah are eight categories of beneficiaries and are very clearly specified in al-Quran as mentioned in Surah al-Tauba (9:60) below:

Zakah expenditures are only for the poor and for the needy and for those employed to collect [zakah] and for bringing hearts together [for

International Journal of Management and Applied Research, 2020, Vol. 7, No. 1 
Islam] and for freeing captives [or slaves] and for those in debt and for the cause of Allah and for the [stranded] traveler - an obligation [imposed] by Allah. And Allah is Knowing and Wise.

The above Quranic verse specifies very clearly that zakah recipients are: the poor, the needy, managers of zakah, reverts to Islam, captives, defaulting debtors, for any good cause in the name of Allah, and travellers.

\subsection{Literature Review on Zakah}

While few studies have examined zakah either as an alternative tool to riba or as a tool to promote ethics and empower the masses in Muslim societies, many have analysed it as a method to eradicate poverty.

With reference to zakah as a tool to eradicate poverty, many sources have been found on the issue. For example, Abdel Mohsin and Alhabshi (2016) show that zakah is a poverty alleviation tool and a charity instrument for eradicating poverty. Similarly, Mohamad and Rahim (2012) assert that zakah could be instrumental in alleviating poverty in Sarawak, Malaysia. As such, they suggest that improved monitoring, administration, and management of the wealth redistribution process, as well as increased transparency and creativity in reaching zakah recipients, need to be addressed in tackling poverty in the state. Shah and Hassan (2017) agree that zakah has an inherent potential to eradicate poverty, particularly in Malaysia. However, they also suggest increased collaboration with other agencies, especially at the state level, to provide much needed poverty reduction programmes in addition to augmenting zakah distribution to bona fide asnafs and ensuring transparency in the various zakah managing organizations.

In a study involving thirteen Indonesian regions, Pickup et al. (2018) reported that zakah had a profound effect on poverty reduction in the country. They concluded that the average monthly income among the zakah recipients rose 27 percent after receiving zakah. Likewise, Islamic Research and Training Institute (2015) showed positive implications brought by zakah collection and distribution in Nigeria and Sudan.

Sadeq (1997) submits that zakah's effect on macroeconomic policies affecting growth and poverty might be limited because most policies are championed by governments. He further submits that in this parlance zakah's chief role would be to redistribute resources. However, he agrees that zakah could play a more decisive role at the micro level. Moreover, Sadeq (1997) argues that while zakah may provide much needed assistance in poor unproductive households (e.g. the physical, human, and financial resources to tackle poverty), in justifiable "unproductive cliques" (i.e. widows, the aged, indisposed, and disabled), zakah institutions would instead deliver regular handouts to cover basic needs.

Abdul Razak (2019) after examining the causes and possible solutions for poverty alleviation called for restructuring the current role of zakah and putting it into practice to mitigate poverty. Trying to solve the problem from an Islamic perspective, he analyses the roles of zakah and awqaf and submits that while the Law Giver stipulated eight rightful beneficiaries in Quran, a consensus exists that priority should be given to

International Journal of Management and Applied Research, 2020, Vol. 7, No. 1 
the poor and needy as regards the distribution of zakah proceeds. Similarly, Al Qardawi stated that the main rationale behind levying zakah is to alleviate poverty or as Islamic fiqh literature puts it, to "better the lot of the poor". With reference to the inclusion of all zakahable wealth for poverty eradication zakah (1989) suggested that zakah can eradicate poverty if all forms of wealth are zakahable and wealth from all sectors is included. Abdul Razak (2019) emphasizes the need to include zakah in the scheme of poverty reduction programmes. Zakah will only have the capacity to harness the additional funds needed if, and only if, workable policies are issued to bolster the third sector, housing institutions commensurate to those administering the private sector in many relevant economies.

With reference to zakah as a tool to eliminate riba, only a small amount of literature has been written on the issue. For example, Abdel Mohsin and Alhabshi (2016) reassure that zakah can play a vital role as an alternative socio-financial tool to riba, if zakah collection becomes compulsory and collected from all zakahtable wealth. As a result, an immense amount of funds will be collected to be distributed, thus putting to an end external borrowing with riba for anti-poverty programs. Similarly, Kaleem and Ahmed (2010) highlight zakah's role as a source of funds for Islamic microfinancing. Such funds could be also used to advance interest-free loans to support consumption and to enable production, the cumulative effect of which would be to alleviate poverty. Similarly, Muneeza (2017) asserts that zakah is a tool to establish sustainable development for mankind, as zakah creates a collective social security scheme for mutual benefit and kindness among Muslim communities.

\subsection{Zakah Management}

Zakah management was centralized for 1300 years under governance of the state from the time of the Prophet (PBUH) until the end of the Ottoman Empire. At the beginning of the twentieth century and with the collapse of the Ottoman Empire, obligatory zakah has been replaced with tax while its collection became voluntary in nearly all Muslim countries.

\subsection{Justification for State to Manage Zakah}

The following hadith authenticates that zakah must be managed by the state even if the state will tamper with it later:

Anas narrates that "a man asked the Messenger of Allah (pbuh), If I give zakah to the person you send, would I be fulfilling it as far as Allah and His Messenger are concerned?' The Prophet answered, 'Yes, if you give it to my messenger, you are freed from that obligation as far as Allah and His Messenger are concerned. You deserve its reward, and if it is tampered with later, the sin is on whoever changes it." (Nail al Awtar, Vol. 4, p. 155).

One may ask why zakah must be given to the state? There are many justifications for such question: one is mentioned in above hadith, as to free the Muslim from such obligation during the Day of Judgment, and the others had been postulated by Islamic scholars (Al-Qardawi 1999) and are listed below:

International Journal of Management and Applied Research, 2020, Vol. 7, No. 1 
- State has a wider vision on the true zakah recipients, so by giving to right recipients this will satisfy the basic needs of the recipient and hence, end their poverty.

- State has a great role in changing the recipients of zakah to givers of zakah in the nearest future.

- Some eligible Muslims may not know how to pay their dues hence the zakah manager can help them.

- Collection of zakah by the state will encourage Muslims to fulfil their obligations through the right channels, so releasing them from this obligation in the Hereafter.

- Regular collection of zakah will promote a good ethic: from being greedy or miserliness to being kind and generous in giving and hence, create a society based on brotherhood.

- For the poor to receive $z a k a h$ directly from the state will enable them to preserve their dignity and avoid humiliation.

- Finally, collecting zakah from all eligible Muslims and from all the fourteen types of zakahable wealth will not only help in distributing the wealth in a just manner but will prevent zakah recipients from borrowing with riba/interest to meet their crucial needs hence, will prevent government from getting external borrowing to finance any poverty program.

\subsection{Objectives of Zakah}

Zakah is not only a socio-financial mechanism for regulating wealth, but it is a domestic financial scheme to enhance ethical behaviour in society besides financing its recipients in an ethical manner to enable comfortable living for all. The main objectives of zakah as gleaned from the Quran are three:

\subsubsection{Wealth Distribution}

As mentioned in the above Quranic verse b y Nail al Awtar ( Vol. 4, p. 155), such compulsory giving has to circulate the wealth from 'the have' to 'the have not', and not only to be circulated among the rich. Only then the gap between the rich and the poor will be narrowed since such circulation has to empower the recipients of zakah to be givers of zakah in the following few years.

Whatever (from the possessions of the towns people) Allah has bestowed on His Messenger belongs to Allah, and to the Messenger, and to his kinsfolk, and to the orphans, and to the needy, and to the wayfarer so that it may not merely circulate between the rich among you. So accept whatever the Messenger gives you, and refrain from whatever he forbids you. And fear Allah: verily Allah is Most Stern in retribution (Sura al Hashir, 59:7).

\subsubsection{An Act of Devotion}

Through compulsory giving zakah, as part of belief, this will uplift the spirit of man beyond the love of material attainment as it purifies and blesses the souls of zakah giver from any selfishness and greediness besides, purifying and blessing the souls of zakah recipients from any hatred, jealousy and laziness hence enhance an ethical and caring society. This is clearly mentioned in the following Quranic verse:

International Journal of Management and Applied Research, 2020, Vol. 7, No. 1 
Take, [O, Muhammad], from their wealth a charity by which you purify them and cause them increase, and invoke [Allah's blessings] upon them. Indeed, your invocations are reassurance for them. And Allah is Hearing and Knowing (Surah Al-Taubah, 9: 103).

\subsubsection{Reduction of Usury}

As mentioned in the following Quranic verse, if people lend to others with interest aiming to increase their wealth, it will not increase with Allah. But if they give in zakah, desiring the countenance of Allah their accomplishments is to be abundant.

And what you give for usury to increase in (the) wealth (of) people, not (will) increase with Allah. But what you give of zakah desiring (the) Countenance (of) Allah, then those [they] (will) get manifold (Surat alRum, 30:39).

\subsection{Challenges and Obstacles Facing Zakah Today}

For several decades, the role of zakah has been stagnant in Muslim countries. Its collection became voluntary (giving directly to those deemed to be the deserving poor), there was no adequate documentation of zakah collection and distribution, the rights of recipients of zakah have been overlooked, a huge amount of external debt has been accumulated by anti-poverty programs and widespread poverty has been propagated throughout the Islamic world.

\subsubsection{Voluntary contributions}

Currently, the collection of zakah -- either through public or private organisations -- is considered voluntary in most of the Muslim countries. There are six Muslims majority countries have mandatory zakah collection systems, these are: Libya, Malaysia, Pakistan, Saudi Arabia, Sudan, and Yemen. These countries have varying degree of enforcement in collecting zakah. In Malaysia, authorities have difficulty enforcing zakah payment despite zakah is mandatory in the nation (Powell, 2010). In countries like Oman and Nigeria, the collection and distribution of zakah is administered by governmental departments although zakah is voluntary in those countries (Hasan, 2015). The zakah administration in selected Muslims countries is illustrated in Table 1.

Table 1: Zakah Administration in Selected Muslim Countries

\begin{tabular}{|c|c|c|c|}
\hline Country & Government & Private & Collection \\
\hline Afghanistan & No government system & N/A & None \\
\hline Algeria & No government system & N/A & None \\
\hline Bahrain & Regulated by state & Zakat Fund & Voluntary \\
\hline Bangladesh & Regulated by state & Zakat Fund & Voluntary \\
\hline Egypt & Regulated by state & $\begin{array}{c}\text { Nasser Socialist Bank; } \\
\text { Zakat foundation of Egypt }\end{array}$ & Voluntary \\
\hline Indonesia & $\begin{array}{c}\text { Regulated by state; } \\
\text { National Board of Zakat Republic } \\
\text { of Indonesia }\end{array}$ & $\begin{array}{c}\text { Semi-autonomous zakat } \\
\text { agencies }\end{array}$ & Voluntary \\
\hline Iran & Overseen by government & bonyads & Voluntary \\
\hline Jordan & Ministry of Awqaf & Zakat Fund & Voluntary \\
\hline Kuwait & Ministry of Awqaf & Zakat House & Voluntary \\
\hline Libya & General Directorate for Zakat & N/A & Compulsory \\
\hline Malaysia & State Islamic Affairs Councils & Regional institutions & Compulsory \\
\hline
\end{tabular}

International Journal of Management and Applied Research, 2020, Vol. 7, No. 1 
A Fresh View On Zakah As A Socio-Financial Tool To Promote Ethics, Eliminate Riba And Reduce Poverty

\begin{tabular}{lccc}
\hline Nigeria & State governments & N/A & Voluntary \\
Oman & Ministry of Religious Affairs and & Endowments & N/A \\
& Ministry of Religious Affairs; State & Zakah Councils & Compulsory \\
Pakistan & Bank of Pakistan Karachi & N/A & Compulsory \\
Saudi Arabia & General Authority of Zakat \& Tax & N/A & None \\
Senegal & No government system & N/A & None \\
Somalia & No government system & N/A & Compulsory \\
Sudan & Diwan Zakah & Private institutions & Voluntary \\
Turkey & No government system & N/A & Compulsory \\
Yemen & Administration of Duties & & \\
& Overseen by government; & UAE Zakat Fund & Voluntary \\
UAE & Minister of Justice, Islamic Affairs & & \\
& and Endowments & Source: Hasan, 2015; Powell, 2010
\end{tabular}

The current situation of zakah administration shows that its role has been stagnant for decades and its collection becomes voluntary in almost all Muslim countries even though zakah constitutes the third pillar of Islam.

\subsubsection{Lack of zakah documentation}

Realization is fast dawning that zakah management is inefficient in the Islamic world, especially regarding the documentation on collection and distribution, as seen in Table 2 , indicating the deficiency of available data.

Table 2: Zakah Collection and Distribution (2000-2015) in Millions USD*

\begin{tabular}{|c|c|c|c|c|}
\hline \multirow[b]{2}{*}{ Country } & \multicolumn{2}{|c|}{ Zakah collection } & \multicolumn{2}{|c|}{ Zakah distribution } \\
\hline & $2000 s$ & $2010 s$ & $2000 s$ & $2010 s$ \\
\hline Afghanistan & -- & -- & -- & -- \\
\hline Algeria & - & $12.7(2014)$ & -- & -- \\
\hline Bahrain & $34.5(2005)$ & -- & -- & -- \\
\hline Egypt & -- & $285(2011)$ & -- & -- \\
\hline Indonesia & -- & $363.9(2016)$ & -- & $201(2016)$ \\
\hline Iran & -- & -- & -- & -- \\
\hline Iraq & -- & -- & -- & -- \\
\hline Jordan & -- & -- & -- & -- \\
\hline Malaysia & -- & $446(2012)$ & -- & 366 (2016) \\
\hline Nigeria & -- & $3(2013)$ & -- & -- \\
\hline Oman & -- & -- & -- & -- \\
\hline Pakistan & $30(2005)$ & -- & $24.15(2005)$ & -- \\
\hline Saudi Arabia & -- & $8000(2015)$ & -- & -- \\
\hline Senegal & -- & -- & -- & -- \\
\hline Somalia & -- & -- & -- & -- \\
\hline Sudan & -- & 22.5 (2013) & -- & $20.5(2012)$ \\
\hline Syria & -- & -- & -- & -- \\
\hline Tunisia & -- & -- & -- & -- \\
\hline Turkey & -- & -- & -- & -- \\
\hline Yemen & -- & -- & -- & -- \\
\hline UAE & -- & $51(2017)$ & -- & $53(2017)$ \\
\hline
\end{tabular}

Source: Data was collected by the author from official websites listed in Appendix A.

*All original currency figures were converted to USD

International Journal of Management and Applied Research, 2020, Vol. 7, No. 1 
Table 2 above substantiates the lack of data about zakah collection and distribution in selected Muslim countries. This may reflect one of the factors contributing to the widespread of poverty in the Islamic world.

\subsubsection{Poverty in the Islamic world}

Table 3 shows that poverty is widespread in Muslim countries. For example; $54.5 \%$ of the total population in Afghanistan are living below national poverty line, in Nigeria 46.7\%, in Afghanistan 54.5\%, whilst in Syria, a staggering $82 \%$.

Table 3: Poverty in Muslim countries 2015-2017

\begin{tabular}{|c|c|c|c|}
\hline Country & $\begin{array}{c}\text { Total } \\
\text { population } \\
2017 \\
\text { (millions) } \\
\end{array}$ & $\begin{array}{c}\text { Muslim } \\
\text { population } \\
2017 \\
(\%) \\
\end{array}$ & $\begin{array}{c}\text { People living below } \\
\text { national poverty line } \\
\text { 2015-2017 } \\
(\%) \\
\end{array}$ \\
\hline Afghanistan & 35.5 & 99.7 & 54.5 \\
\hline Bahrain & 1.5 & 73.7 & N/A \\
\hline Bangladesh & 170 & 90.4 & 24.3 \\
\hline Egypt & 97.5 & 94 & 27.8 \\
\hline Indonesia & 264.9 & 87.2 & 28.1 \\
\hline Iran & 83 & 99.4 & N/A \\
\hline Iraq & 40.2 & 95.7 & 23 \\
\hline Jordan & 10.5 & 97.2 & 14.2 \\
\hline Kuwait & 2 & 74.6 & N/A \\
\hline Malaysia & 32.6 & 61.3 & 19 \\
\hline Morocco & 38.3 & 99 & 15 \\
\hline Nigeria & 214 & 53.5 & 46.7 \\
\hline Oman & 4.6 & 85.9 & N/A \\
\hline Pakistan & 207.7 & 96.5 & 24.3 \\
\hline Saudi Arabia & 33.4 & 97.1 & N/A \\
\hline Senegal & 15.8 & 96.1 & 46.7 \\
\hline Somalia & 11.7 & 99.8 & N/A \\
\hline Sudan & 45.5 & 97 & 46.5 \\
\hline Syria & 19.3 & 87 & 82.5 \\
\hline Tunisia & 11.7 & 99.1 & 15.5 \\
\hline Turkey & 82.3 & 99.8 & 13.5 \\
\hline Yemen & 29.8 & 99.1 & 54 \\
\hline UAE & 9.9 & 76 & 19.5 \\
\hline
\end{tabular}

Data collection is challenging in some countries due to political conflict and unrest, and thus some of the figures presented in Table 3 are estimates.

\subsubsection{Lack of data on all types of zakahable wealth}

Islamic Research and Training Institute (2015) indicates that there is no regular data collection on zakah from all the fourteen types of zakahable wealth in almost all Muslim countries with the exception of Nigeria and Sudan. Zakahable wealth includes

International Journal of Management and Applied Research, 2020, Vol. 7, No. 1 
livestock, gold, silver currency, jewellery, commercial assets, agriculture, honey and animal products, profits from mining and fishing, rented buildings, plants, and fixed capital. Hence, if all these fourteen types of zakahable wealth are collected than an immense amount of zakah funds would be accumulated and that would help with alleviating the poverty in the Islamic world. However, the lack of adequate control of zakah management in the Islamic world today represents an obstacle towards poverty alleviation. For example, in Nigeria, zakah institutions collect cash, livestock and agricultural products yet the amount is negligible (Ahmad, 2019). Similarly, in Sudan, even though zakah institutions collect a wider range of assets, including, livestock, mining, trade inventory, rented buildings and salaries (Islamic Research and Training Institute, 2015) yet insufficient governance of zakah management does not allow for higher collection of zakah. Hence, deficiencies in organising sound governance of zakah and the lack of understanding of its remarkable role in the Islamic world are likely to be symptomatic of deterioration of interest in zakah despite its Quranic origin.

\subsubsection{Borrowing with interest (riba) for poverty alleviation programs}

Even though zakah money must be obtained from the above mentioned zakahable wealth yet it does not happen. Hence, most Muslim countries are facing a shortage of funds to finance their anti-poverty programs. This in turn forces governments to borrow funds with interest in order to finance such programs. As a result, Muslim countries are subject to the trap of compound interest as exemplified in the case of Nigeria. Although Nigeria benefited from massive debt relief, the nation's public debt exceeds $\$ 80$ billion at the end of June 2019 (Debt Management Office Nigeria, 2019). Moreover, Nigeria's debt profile is increasingly made up of commercial debt, limiting the country from escaping its self-inflicted debt trap (Brannon, 2019). Hence, through borrowing with interest Nigeria will continue repaying back the loan while poverty will persist for generation to come. Table 4 shows that not only Nigeria but other Muslim countries are trapped into borrowing with interest (riba).

Table 4: Total Lending by World Bank between 1970 and 2020 for Poverty Alleviation Programs

\begin{tabular}{lcc}
\hline Country & $\begin{array}{c}\text { Total Lending } \\
\text { (USD millions) }\end{array}$ & $\begin{array}{c}\text { Interest Rate } \\
(\boldsymbol{\%})\end{array}$ \\
\hline Bangladesh & 54 & 9.7 \\
Chad & 39 & - \\
Egypt & 20,390 & 18.3 \\
Indonesia & 54,913 & 10.5 \\
Jordan & 6,568 & 8.7 \\
Malaysia & 3,915 & 4.9 \\
Morocco & 18,669 & - \\
Nigeria & 6,687 & 16.9 \\
Pakistan & 10,583 & 8.5 \\
Senegal & 155 & 5.1 \\
Sudan & 32 & 16.2 \\
Syria & 579 & - \\
Tunisia & 10,473 & - \\
Turkey & 42,006 & - \\
\hline Source: World Bank Group Finances (2020) and World Bank (2019)
\end{tabular}

International Journal of Management and Applied Research, 2020, Vol. 7, No. 1 
As seen above, majority of Muslim countries find themselves caught in a poverty situation due to the amount of interest paid on loans which they will likely continue to pay for generations to come. The question that may arise is whether zakah has the potential to stop borrowing with riba/interest for anti-poverty programs, eradicate poverty and spread ethical environment in the Islamic world, if its collection becomes compulsory and its management become efficient. This question will be analysed below.

\section{Current and Innovative Ways in Managing Zakah Today}

For zakah to meet its objectives today, it is vital for governments in Muslim countries to recognize its importance as the third pillar of Islam and as a compulsory due to be given to the state to meet its objectives. As such, it is Muslim compulsory upon Muslims to give zakah on regular basis from all types of zakahable wealth they own. Ideally, zakah is a compulsory levy, collected by the government from all eligible Muslims to be redistributed to eight recipients as mentioned in al-Quran. Zakah managers, in turn, should be trained to facilitate efficient zakah management and ensure that zakah is redistributed to its eligible recipients in a way that empower them to be active contributor to the society. In this way, they will become zakah givers in future.

\subsection{Zakah Collection from Salary and its Immense Amount}

In Islam, it is acceptable for zakah to be remitted on a monthly basis, if payment is made in advance. It has been reported that the Prophet (PBUH) accepted zakah from his uncle, Al-Abbas, two years in advance because of Muslim need at that time (Al Qardawi, 1999).

Today, most of the Muslim population earn monthly salaries, so excluding such type of zakahable wealth may therefore result in shortages of funds which could otherwise have been used to help eradicate poverty. This realisation encouraged some Muslim countries, such as Sudan, to enact laws for compulsorily collection of zakah on salaries, while other countries like Malaysia chose to do it on a voluntary basis. For example, the Income Tax Act 1967 in Malaysia encourages Muslims to pay zakah on monthly basis through tax rebates without affecting their net payment (Abdul Razak, 2019; Abdullah and Sapiei, 2018). This means that such zakahable wealth can be summed up as the liquid assets a Muslim possesses after deducting short term liabilities. Assets include cash and savings while liabilities include debts and expenses. Once all expenditure has been deducted from the total annual gross income, the balance, if it reaches al-nisab, will be subject to zakah of $2.5 \%$. At the end of each year, the zakah giver has to recalculate his zakah value again and in the case where the savings are higher than previously estimated, then the outstanding balance should be given to the department managing zakah. In the case of the zakah giver incurring higher costs than previously calculated (e.g. unexpected expenses) with evidence in the form of receipts or bills supporting the unexpected expenditure, a refund of the overpaid balance should be arranged by the department managing zakah.

A study conducted by Mohsin (2011) has shown that substantial amounts of zakah can be collected from zakah al-fitr and the potential givers' salaries. Assume that zakah

International Journal of Management and Applied Research, 2020, Vol. 7, No. 1 
becomes compulsory in country A with a Muslim population of 32 million of which 5 million are rich, 10 million are the middle class, and 17 million are less productive members of society (i.e. young, elderly, poor and in other needs). In this scenario, if country A would have its zakah al-fitr at \$1 USD dollar, then the amount of $\$ 32$ million can be collected within one month only. This amount of money would be a tremendous help in supporting the basic needs for the poor and needy, if efficient management. Similarly, with reference to zakah from salary, if the rich give USD1000 per year as their zakah and the middle class give USD100 per year then a total amount of USD6 billion of US Dollars will be collected within a year as shown in Table 5 below.

Table 5: Total Annual Collection of Zakah from Salary

\begin{tabular}{lccc}
\hline Social class & $\begin{array}{c}\text { Working Population } \\
\text { (millions) }\end{array}$ & $\begin{array}{c}\text { Zakah per } \\
\text { year (USD) }\end{array}$ & $\begin{array}{c}\text { USD } \\
\text { (billions) }\end{array}$ \\
\hline Upper class & 5 & 1000 & 5 \\
Middle class & 10 & 100 & 1 \\
Total & 15 & & 6 \\
\hline
\end{tabular}

Extrapolating from the above example, one could calculate the amount of potentially collectable of zakah funds in selected Muslim countries as presented in Table 6. It is assumed that the collection of zakah is being organised on a compulsory basis with rich givers contributing an average annual rate of USD1000/person and USD100/person being remitted by the middle-class givers.

Table 6: Zakah collection from salary

\begin{tabular}{lcccccc}
\hline Country & $\begin{array}{c}\text { Muslim } \\
\text { population } \\
\text { (mil) }\end{array}$ & $\begin{array}{c}\text { Upper } \\
\text { class } \\
(\text { mil) }\end{array}$ & $\begin{array}{c}\text { Middle } \\
\text { class } \\
(\text { mil) }\end{array}$ & $\begin{array}{c}\text { Upper class } \\
\text { giving } \\
\text { USD1000 } \\
\text { zakah } \text { per } \\
\text { year } \\
\text { (bil) }\end{array}$ & $\begin{array}{c}\text { Middle class } \\
\text { giving } \\
\text { USD100 } \\
\text { zakah } \text { per } \\
\text { year } \\
\text { (bil) }\end{array}$ & $\begin{array}{c}\text { Total } \text { zakah } \\
\text { collection } \\
\text { from salary } \\
\text { in USD } \\
\text { (bil) }\end{array}$ \\
\hline Bahrain & & & & 0.2 & 0.05 & 0.25 \\
Bangladesh & 135.1 & 27 & 73 & 27 & 7.3 & 34.3 \\
Egypt & 77.7 & 15.5 & 42.6 & 15.5 & 4.26 & 19.76 \\
Indonesia & 218 & 43.6 & 150 & 43.6 & 15 & 58.6 \\
Iran & 77.1 & 15.4 & 47 & 15.4 & 4.7 & 20.1 \\
Iraq & 33 & 6.6 & 20 & 6.6 & 2.0 & 8.2 \\
Jordan & 4.4 & 0.9 & 2.9 & 0.9 & 0.29 & 1.19 \\
Malaysia & 18.3 & 3.7 & 14.3 & 3.7 & 1.43 & 5.13 \\
Morocco & 32 & 6.4 & 25.5 & 6.4 & 2.55 & 8.95 \\
Nigeria & 83 & 16.6 & 28 & 16.6 & 2.8 & 19.4 \\
Oman & 3.2 & 0.6 & 2.2 & 0.6 & 0.22 & 0.82 \\
Pakistan & 172 & 34.4 & 99 & 34.4 & 9.9 & 44.3 \\
Sudan & 29.9 & 5.8 & 10 & 5.8 & 1 & 6.8 \\
Tunisia & 10.8 & 2.2 & 7 & 2.2 & 0.7 & 2.9 \\
Turkey & 73.9 & 14.8 & 56 & 14.8 & 5.6 & 20.4 \\
& & Total projected zakah collection from salary & 251.1 \\
\hline
\end{tabular}

While Table 6 reflect on an approximate imaginary scenario, it demonstrates the potential of collecting $\$ 251$ billion US dollars worth of zakah from salaries alone in

International Journal of Management and Applied Research, 2020, Vol. 7, No. 1 
twenty-two Muslim countries and that amount will likely keep increasing every year. It needs to be pointed out that the total zakah collection from salary in almost all countries included in the table is in the billions of US dollars, whereas the external debt associated with anti-poverty programs is only in the millions. Hence, this scenario confirms that zakah provides a genuine and logical tool for not only eliminating riba but to eradicate poverty in the Muslim world in a just manner and within a shorter period of time, if all the fourteen zakahable wealth categories have been paid. That said, it needs to be emphasised here that organising the management of zakah on such a scale is a longitudinal and quite complex process, but its outcome, if implemented on such scale, will be no less than phenomenal.

\subsection{Altering Zakah Recipients to become Zakah Givers}

For achieving the above mentioned objective zakah managers need to be innovate in distributing zakah funds to its recipients, in such a way that they will not misuse it and at the same time it will assist them in becoming zakah givers in the following years. This can be achieved by dividing zakah collection into two parts: one part is to be given as zakah cards for meeting basic needs and another part to be given as a zakah income-generating scheme that would help zakah receivers to start their small business.

\subsubsection{Zakah cards scheme}

This scheme will help zakah recipients in fulfilling their basic needs through zakah cards rather than giving them zakah money which they might misused. With this card the poor and the needy can get their five basic needs covered in terms of food, cloth, medication, education and shelter.

\subsubsection{Zakah income-generating scheme}

For this scheme zakah managers have to be proactive and give zakah in kind. This means zakah manager purchases the goods, such as sewing machines for women, boats for fisher men, grass cutters, food stalls etc., and lend them to zakah recipients according to their skills to establish own small business. In case when the business becomes profitable and they would like to buy previously borrowed equipment, then zakah managers can sell it to them at lesser than the market price. In this case zakah managers can help in empowering the poor and need to become active members in the society and become zakah givers in the near future.

Hence, these two schemes will help the poor and needy people not only in terms of satisfying their basic needs, but through zakah income-generating financial scheme recipients can get help with starting their own small business and that would enable them to become active members in their society rather than relying on charitable handouts.

\section{Potential Role of Zakah in Muslim Society Today}

As mentioned earlier, zakah is a socio-financial tool intended to elevate the spirit of human beings beyond the love of material wealth. Hence, reviving the institution of zakah in line with shariah in terms of its compulsory due, its administration and the

International Journal of Management and Applied Research, 2020, Vol. 7, No. 1 
inclusion of all types of zakahable wealth substantial amounts of zakah funds can be collected annually for the following purposes:

\subsection{Promoting Ethics}

As mentioned above by Surah Al-Taubah (9:103), zakah increases the wealth of zakah givers, purifying not only their wealth but also helping them to heal many types of inappropriate behaviour for both sides; the givers and the recipients of zakah within Muslim societies as explained by Al Qardawi (1999).

\subsubsection{Enhance good ethics among zakah givers}

It is contended that the collection of zakah on a regular basis will enhance the ethics of zakah givers by purifying their souls of miserliness as such selfless generosity emanates from submission to the command of Allah. Moreover, zakah would also liberate their souls from an overwhelming love of wealth or material gains. Also the regular payment of zakah could be used as a means to train Muslims in the virtues of generosity which in turn could also benefit other charitable causes.

\subsubsection{Enhance good ethics among zakah recipients}

Similarly, the distribution of zakah on a regular basis will purify zakah recipients' souls of envy and hatred towards the rich, especially if it is transferred to them on a regular basis helping them to find their living. Further, zakah frees the beneficiary from the humiliation of receiving a handout directly from his/her neighbour whilst also helping to satisfy his or her basic needs leading to a good and prosperous life for all.

\subsubsection{Promote the concept of brotherhood in Muslim society}

If zakah is managed efficiently and according to the teachings of Islam, healthy and ethical societies will be realized in Muslim countries by which the undesirable behaviours of selfishness, greed, hatred, jealousy and laziness between zakah givers and recipients will be transformed into kindness and create a caring society. Moreover, the act of regularly giving zakah will have the effect of circulating the wealth from zakah givers to zakah recipients hence, cultivating a culture of brotherhood between the rich and poor. Similarly, fulfilling the obligation of giving zakah is a blessing from Allah (SWT) which will bring prosperity to all, hence will achieve one of the objectives of zakah as an alternative to riba.

\subsection{Eliminating Riba}

As highlighted above, aside from inefficient management of zakah, riba plays a great role in spreading poverty in the Islamic world. Despite Islam's prohibition of riba, which Allah (SWT) replaced with alternative financial and socio-financial institutions including zakah, as came in Surah al-Rum (30:39), Muslim countries resort to external borrowing for their anti-poverty programs as shown in table IV. In this regard one may ask how zakah can replace borrowing with riba for such programs. The answer is surprisingly straightforward. Through government mandated contributions immense amount of zakah funds will be collected, which will enhance the disposable income of the poor and needy, so preventing them from borrowing with riba to meet their crucial needs on one hand and on the other hand, it will assist governments in financing antipoverty programs rather than resorting to external borrowing with riba.

International Journal of Management and Applied Research, 2020, Vol. 7, No. 1 


\subsection{Empowering the Poor and ending Poverty}

Zakah circulates the wealth from 'the haves' to 'the have nots', hence empowering the poor and helping to eradicate poverty. Referencing the two incidents during the time of Caliph Umar ibn al Khattab and during the time of Caliph Umar bin Abdul Aziz, where zakah management was efficient, it has been realized that after a two year period zakah recipients became zakah givers exemplifying that ending poverty in a short period of time is possible (Al Qardawi, 1999). Studying these two inspiring incidents may help us to discover how zakah funds can be collected today, if such contributions were to become compulsory and its management become efficient and transparent.

Similarly, the answer to the question - how zakah can empower the poor and needy and eradicate their poverty can be explained as follows. Government collection of zakah from eligible Muslims and its redistribution according to the eight categories of recipients until all are enriched will enhance the living standards of the poor encouraging them to become future givers. Moreover, taking into account all zakahable wealth will help to redistribute income from 'the haves' to 'the have nots' in a just and equitable manner, thus reducing the gap between rich and poor and helping to eradicate poverty within Muslim societies. In addition, distributing zakah amongst the needy will also have the effect of enhancing aggregate consumption (demand) positively impacting economic growth.

\section{Conclusion}

The above argument led to the realisation that zakah, as it was known in Islam for centuries, has an extraordinary socio-financial potential that has not been fully utilised in recent years. This in turn has compelled governments in Muslim countries to borrow funds with riba in order to delay the spread of poverty, which may have provoked instances of unethical behaviour in the Islamic world. Revitalising the practice of collecting zakah from salary only would provide governments in Muslim countries with sufficient funds to tackle many societal problems including the wide spreading of poverty in particular. However, revitalising the use of zakah on the scale of countries or even a country requires further research and development of government policies to provide a legal basis and to support it across the board implementation.

The practical implication of this paper is in its potential to raise awareness about the importance of collecting zakah on a compulsory basis from all zakahable wealth in order to achieve its purpose in the Islamic world. On the societal level, zakah represents a socio-financial tool for promoting the concept of brotherhood, kindness and generosity besides, empowering the masses. Its use would reduce or even stop borrowing with riba, which in turn would position it towards eradicating poverty in Muslim societies.

\section{References}

1. Abdel Mohsin, M. I. (2011), "Zakah from salary and EPF: issues and challenges", International Journal of Business and Social Science, Vol. 2, No. 1, pp. 278-286.

International Journal of Management and Applied Research, 2020, Vol. 7, No. 1 
2. Abdel Mohsin, M. I. (2013), "Potential of zakah in eliminating riba and eradication poverty in Muslim countries", Islamic management and Business, Vol. 5, No. 11, pp. 114-126.

3. Abdel Mohsin, M. I. and Alhabshi, S. (2016), "Hybrid model of zakah, waqf, qardhassan \& Islamic finance for a just and sustainable microfinance", Sahulat Journal, Vol. 4, No. 1, pp. 27-46.

4. Abdul Razak, S. H. (2019), "Zakah and waqf as instrument of Islamic wealth in poverty alleviation and redistribution: Case of Malaysia", International Journal of Sociology and Social Policy, https://doi.org/10.1108/IJSSP-11-2018-0208

5. Abdullah, M. and Sapiei, N. (2018), "Do religiosity, gender and educational background influence zakah compliance? The case of Malaysia", International Journal of Social Economics, Vol. 45 No. 8, pp. 1250-1264.

https://doi.org/10.1108/IJSE-03-2017-0091

6. Ahmad, M. (2019), "An empirical study of the challenges facing zakah and waqf institutions in Northern Nigeria", ISRA International Journal of Islamic Finance, Vol. 11, No. 2, pp. 338-356. https://doi.org/10.1108/IJIF-04-2018-0044

7. Al Qardawi, Y. (1999), Fiqh al-Zakah: A Comparative Study of Zakah, Regulations and Philosophy in the Light of Qur'an and Sunnah, trans. by Monzer Kahf, Scientific Publishing Centre, King Abdulaziz University Jeddah, Saudi Arabia.

8. Bilo, C. and Machado, A. (2019), "The role of Zakah in the provision of social protection: A comparison between Jordan and Sudan", International Journal of Sociology and Social Policy, https://doi.org/10.1108/IJSSP-11-2018-0218

9. Brannon, I. (2019), "Nigeria's Deceptively Large External Debt Could Threaten Its Economy", Forbes, [Online] available from: https://www.forbes.com/sites/ikebrannon/2019/08/06/nigerias-deceptively-largeexternal-debt-could-threaten-its-economy/ [Accessed on 12 December 2019].

10. Central Intelligence Agency (CIA) (2020), The World Factbook, [Online] available from: https://www.cia.gov/library/publications/resources/the-world-factbook/ [Accessed on 12 December 2019].

11. Debt Management Office Nigeria (2019), Nigeria's total public debt portfolio as at June 30 2019, [Online] available from: https://www.dmo.gov.ng/debt-profile/totalpublic-debt/2950-nigeria-s-public-debt-as-at-june-30-2019/file [Accessed on 12 December 2019].

12. Hasan, S. (2015), Human Security and Philanthropy: Islamic Perspectives and Muslim Majority Country Practices, New York: Springer.

13. Islamic Research and Training Institute (2015), Islamic Social Finance Report $1436 \mathrm{H}$, Jeddah: Islamic Research and Training Institute.

International Journal of Management and Applied Research, 2020, Vol. 7, No. 1 
14. Kaleem, A. and Ahmed, S. (2010), "The Quran and poverty alleviation: a theoretical model for charity-based Islamic microfinance institutions (MFIs)", Non-Profit and Voluntary Sector Quarterly, Vol. 39, No. 3, pp. 1-22. https://doi.org/10.1177\%2F0899764009332466

15. Muneeza, A. (2017), "Administration of Zakah on Wealth in Maldives", International Journal of Management and Applied Research, Vol. 4, No. 1, pp. 58-71. https://doi.org/10.18646/2056.41.17-006

16. Pickup, F.; Beik, I. S. and Buana, G. K. (2018), Unlocking the Potential of Zakah and Other Forms of Islamic Finance to Achieve the SDGs in Indonesia, Indonesia: United Nations Development Programme.

17. Powell, R. (2010), "Zakat: Drawing Insights for Legal Theory and Economic Policy from Islamic Jurisprudence”, University of Pittsburgh Tax Review, Vol. 7, pp. 43-101.

18. Sadeq, A. (1997), "Poverty Alleviation: An Islamic Perspective", Humanomics, Vol. 13, No. 3, pp. 110-134. https://doi.org/10.1108/eb018797

19. Shah, R. N. and Hassan, R. (2017), "Zakāh Collection and Distribution Framework in Federal Territory of Kuala Lumpur: A Study on Selected Islamic Banking Institutions", International Journal of Management and Applied Research, Vol. 4, No. 1, pp. 3-16. https://doi.org/10.18646/2056.41.17-002

20. World Bank (2019), Lending Interest Rate, [Online] available from: https://data.worldbank.org/indicator/FR.INR.LEND [Accessed on 12 December 2019].

21. World Bank (2020), Poverty and Equity Data Portal, [Online] available from: http://povertydata.worldbank.org/poverty/home/ [Accessed on 12 December 2019].

22. World Bank Group Finances (2020), IBRD/IDA Summary, [Online] available from: https://financesapp.worldbank.org/en/summaries/ibrd-ida/\#ibrd-len/ [Accessed on 12 December 2019].

\section{Appendix A}

The following websites, news, and academic studies on zakah comprise the sources of information for presenting Table 2:

Algeria

Algerian Radio (2014), Zakah Revenue for 2014, [Online], available from: http://www.radioalgerie.dz/news/ar/article/20141106/18905.html (accessed 27 March 2019).

Bahrain

International Journal of Management and Applied Research, 2020, Vol. 7, No. 1 
Al-Muslim, A. M. J. (2007), "Secretarian Funds", Al Wasat News [Online], available from: http://www.alwasatnews.com/news/print/262012.html (accessed 27 March 2019).

\section{Bangladesh}

Shirazi, N. S. and Amin, F. (2009), "Prospect of poverty elimination through potential zakah collection in OIC-member countries: Reappraised", Journal of Islamic

Economics, Banking and Finance, Vol. 6, No. 3, pp. 58-74.

Egypt

Al Arabiya (2011), Zakah Funds [Online], available from:

http://www.alarabiya.net/articles/2011/09/20/167849.html (accessed 27 March 2019).

Indonesia

Pickup, F.; Beik, I. S. and Buana, G. K. (2018), Unlocking the Potential of Zakah and Other Forms of Islamic Finance to Achieve the SDGs in Indonesia, Indonesia: United Nations Development Programme.

Malaysia

Saad, R.A.J.; Md Idris, K.; Shaari H. Sawandi, N. and Derashid, C. (2017),

"Governance of Non-Profit Organizations: A Case of Zakah Institutions in Malaysia", International Journal of Economic Research, Vol. 14, No. 16, pp. 253-265.

Nigeria

Islamic Research and Training Institute (2015), Islamic Social Finance Report 1436 H, Jeddah: Islamic Research and Training Institute.

Pakistan

Abdullah, N., Mat Derus, A. and Al-Malkawi, H. (2015), "The effectiveness of zakah in alleviating poverty and inequalities: A measurement using a newly developed technique", Humanomics, Vol. 31 No. 3, pp. 314-329. https://doi.org/10.1108/H-02-

2014-0016

\section{Saudi Arabia}

Al-riyadh Newspaper (2016). Zakah and Income Authority revenue increased to 30 billion riyals, [Online], available from: http://www.alriyadh.com/1115398 (accessed 27 March 2019).

\section{Sudan}

Islamic Research and Training Institute (2015), Islamic Social Finance Report 1436 H, Jeddah: Islamic Research and Training Institute.

United Arab Emirates

Zakah Fund of the United Arab Emirates (2019), Open Data [Online], available from: https://www.zakahfund.gov.ae/zfp//web/Page_opendata.aspx (accessed 27 March 2019).

International Journal of Management and Applied Research, 2020, Vol. 7, No. 1 